\title{
An Exemplary Story of Growing Temperate Mushroom in Tropical Climate of Rural India: Lessons for Other Startups
}

\author{
Mahantesh Shirur $^{1^{*}}$, N.S. Shivalinge Gowda ${ }^{2}$, M.J. Chandregowda ${ }^{3}$, \\ Sunil $^{2}$ and Rajesh K. Rana ${ }^{4}$
}

${ }^{1}$ Directorate of Mushroom Research, Solan-173 213, HP, India

${ }^{2}$ Department of Agricultural Extension, UAS, GKVK, Bengaluru-560 065, Karnataka, India

${ }^{3}$ ICAR-agricultural technology application research institute, Hebbal, Bengaluru-24, India

${ }^{4}$ ICAR-ATARI, Ludhiana, India

*Corresponding author

\begin{tabular}{|c|c|}
\hline & A B S T R A C T \\
\hline $\begin{array}{l}\text { K e y w o r d s } \\
\text { Mushroom } \\
\text { cultivation, Success } \\
\text { story, } \\
\text { Entrepreneurship, } \\
\text { Entrepreneurial } \\
\text { behaviour, Startups }\end{array}$ & \multirow{3}{*}{$\begin{array}{l}\text { Mushroom cultivation is a remunerative agribusiness in India and other parts of the world. } \\
\text { Being an emerging commercial activity, many startup entrepreneurs are venturing into } \\
\text { mushroom cultivation in India. Consumer demand for a particular mushroom variety } \\
\text { drives entrepreneurs to create environment controlled facilities for growing that particular } \\
\text { mushroom. Growing a temperate mushroom in a tropical climate is advantageous on profit } \\
\text { front but it poses several challenges too. The notion of mushroom as a food of elite and } \\
\text { several other myths associated with its consumption are impeding its spread to rural areas. } \\
\text { A case study of growing temperate mushroom in the tropics of rural India was undertaken. } \\
\text { Based on the project cost and cost of growing a temperate mushroom in the country side of } \\
\text { tropical region, the techno-economic feasibility analysis was carried out in this study. The } \\
\text { observations in the case study have implications for the mushroom entrepreneurship and } \\
\text { mushroom consumption in India and many other tropical countries. Based on the case } \\
\text { study, lessons for startup enterprises are also delineated. }\end{array}$} \\
\hline Article Info & \\
\hline $\begin{array}{l}\text { Accepted: } \\
\text { 23 August } 2017 \\
\text { Available Online: } \\
\text { 10 September } 2017\end{array}$ & \\
\hline
\end{tabular}

\section{Introduction}

Promotion and development of agro-based enterprises in the rural sector can play an important role in diversification of economic activities and generation of employment opportunities for the rural youth (Kumar and Singh, 2014). Mushroom cultivation is an emerging agri-business venture which uses agriculture residue as raw material to yield protein rich food and creating employment and income generation opportunities in India for rural youth. Mushrooms are valued world over for their nutritional and medicinal value since ancient times. Besides having low fat, high proteins and high vitamins, mushrooms contain several minerals (Phosphorous and Potassium) and trace elements (Selenium). Mushrooms also contain dietary fibres and are rich source of bioactive molecules and valuable enzymes with more than 100 therapeutic effects (Marshal and Nair, 2009; Wasser, 2010 and Badalyan, 2012). Mushrooms have been important components of Chinese food and nutritional security policy (Zhang et al., 2014). 
The white button mushroom (Agaricus bisporus)- a temperate mushroom variety requires low temperature $\left(16-18{ }^{\circ} \mathrm{C}\right)$ and high relative humidity $(\mathrm{RH})(85-90 \%)$ during its fruiting and cropping stages (Vedder, 1978; Gils, 1988). On the contrary, most of the regions in India witness a higher temperature and lower RH, making it difficult to grow the button mushroom under natural climatic conditions. In the plains of North Indian villages, farmers grow button mushroom with fair amount of success during the winter months in the temporary thatched houses (Vijay, 2011). They prepare the selective compost required to grow the button mushroom by following "long method of composting". However, the enticing high prices for button mushroom in the local urban markets motivate the farmers in southern India to adopt the cultivation of this mushroom in controlled environment facilities.

Button mushroom is the most preferred mushroom variety in Karnataka (Shirur and Shivalingegowda, 2015). Notwithstanding, the adverse climatic conditions for growing button mushroom, many farmers are creating artificial conditions in-house by employing the chillers and air handling unit (AHU) to grow this variety. These facilities necessitate huge initial investment on their design and recurring expenditure on electricity consumption.

This has serious implications on the cost of producing a unit of fresh mushroom and subsequently its profitability. However, the Kulkarni family of a small village- Tigadi in southern India ventured into a non-traditional enterprise of growing mushroom as a means of diversifying their agriculture operations. Being in the tropical region, the average daily temperature data, recorded from the district headquarter of the village ranges between
25.6-29. $4^{\circ} \mathrm{C}$ during June to January and between $31.7-36^{\circ} \mathrm{C}$ during February to May (ftp://ftp.atdd.noaa.gov/pub/GCOS/WMONormals/RA-II/IN/43198.TXT). Hence, it makes an inquisitive case study of growing a temperate mushroom in a tropical climate in a rural village.

\section{Materials and Methods}

Case study research was undertaken in 2015 for a single complex functioning unit in the natural context with multitude of data collection tools. The Kulkarni farm fresh mushroom growing unit located at Tigadi village of Belagavi district in Karnataka State (Fig. 1) being a highly successful case, was purposively selected for the study.

Personal interviews, structured questionnaires (both closed and open ended) and personal observations were used for data collection, analysis and validation. Purposive selection of the unit for case study among 60 different mushroom growing entrepreneurs and their mushroom units was based on the results of 'entrepreneurial behaviour' and 'performance index' analysis by Shirur (2015). To measure the 'entrepreneurial behaviour' and 'performance index' as a continuous variable, scale developed by Shirur (2015) by following the normalized rank approach (Guilford, 1954) was employed.

The initial capital investment is as reported by the owners of the mushroom production unit. The share of different items is calculated based on the quantity and price of item averaged for one year data. The value of all items is expressed in Indian National Rupees (INR or ₹ ). Based on findings of this study a comprehensive list of lessons and precautions has been presented for the benefit of potential start-ups in mushroom growing business in tropical rural India. 


\section{Results and Discussion}

Reluctance of educated youth to work with soil and animals, hazards of climate, difficult to compete in the business, less remunerative character of farming and difficult to meet family requirements are the reasons for dislike of youths towards farming. Lack of farmers support policy, continuous land fragmentation, lack of facilities for agribusiness, risk and hazards, lack of social security are the major constraints to retain youths in farming for livelihood (Satapathy and Panda, 2014). However, the present case study of educated youth to embrace the agribusiness in the rural India is an exemplary story for many rural youth to emulate.

\section{The past and the progress}

Kulkarni family is involved in agriculture for generations in their native village- Tigadi in Belagavi district of Karnataka. With the changing times, they have adopted to be in sync with development in agriculture and related enterprises. They have diverse crop and animal husbandry enterprises with various crops like sugarcane (Saccharum officinarum), cotton (Gossypium sps.), wheat (Triticum aestivum), jowar (Sorghum sps.), soyabean (Glycine max) along with other horticulture crops like fruits and vegetables. Kulkarni dairy farm established in 2005 with 100 milking buffaloes, grew to house more than 300 Buffaloes and 25 exotic breeds of cows with a daily milk production capacity of 1500 litres within five years.

The new generation brothers of the Kulkarni family; $\mathrm{Mr}$ Satish, $\mathrm{Mr}$ Shrikar and $\mathrm{Mr}$ Jayatheerth conceived the idea of having their mushroom production unit after continuously seeing the high prices for mushrooms in the markets of Mumbai, Pune and Bengaluru. Mr Satish, a marketing executive with a multinational company was quick to assess the growing demand for mushrooms in Indian vegetable market and also to foresee a huge scope for exporting the same to other countries, especially to the Middle East and West Asian countries.

In the first place, the owners of the mushroom unit ascertained the total demand for fresh mushrooms from leading wholesalers of major cities in their region. After deciding to venture into mushroom cultivation, they contacted the IDBI bank for loan and National Horticulture Board, Regional branch office at Bengaluru for subsidy on mushroom projects. Then they registered it as a company, and applied for loan and subsidy. The project cost was nearly ₹ 40 million. However, by the end of farm designing and establishment, the expenditure crossed ₹ 46 million due to inflation and differences in the costing, scale and added machinery. The details of capital investment on different headings are presented in figure 2 . They availed around 4 million rupees as the subsidy.

The owners along with their managerial staff attended a 10 day training on mushroom cultivation technology for entrepreneurs during April, 2010 at ICAR-Directorate of Mushroom Research, Solan (HP). After the training, they assessed the availability of raw materials for compost like straw, sugarcane (Saccharum officinarum) bagasse, gypsum, poultry manure etc. and started procuring from nearby places. The spawn was procured either from Pune or Delhi for initial few months as the spawn production unit could not be commenced along with mushroom production unit. Huge cost of spawn, cost on its transportation and not having control over the quality forced them to start their own spawn unit subsequently. The required technical, managerial and skilled labour were bought from North Indian villages to train the local villagers on different skilful aspects of mushroom cultivation like, the compost 
preparation, the spawn preparation, inoculation, spawning, crop management etc.

After setting up the mushroom production unit, they registered the name under the Companies Registration Act, 'Kulkarni Farm Fresh Limited' which was incorporated in February 2010. At present, the mushroom unit is producing around 400-410 t (t) against the annual installed capacity of $500 \mathrm{t}$.

\section{Startup constraints}

Mushroom cultivation as an entrepreneurship, poses several challenges to growers. Many of the constraints are in the farm designing and preparation stage, while few other problems are encountered during the subsequent stages of crop management and marketing. Some of the constraints reported in mushroom entrepreneurship are listed in table 1 .

The Kulkarni farm fresh mushroom unit encountered several problems while designing and construction of the plant especially with respect to the insulation material, their design, cooling facility, the type of coolant to be used, designing of the compost pasteurization tunnels, etc. However, with technical inputs from Scientists of ICAR-Directorate of Mushroom Research, Solan, they managed to start the production in 2011. The lack of ready standards for proper design and distance of ICAR-Directorate of Mushroom Research were main reasons for delay in the commencement of the project, which led to financial burden on account of debt servicing. In the beginning, lack of skilled labour and competent managerial staff was major constraint. The fluctuation in daily mushroom production because of inconsistency in compost and spawn quality added to the woes of this mushroom unit.

Gradually, the owners and the managerial staff in the unit learnt the lessons and attained stability in the production and productivity.
However, they recall that managing the recurring expenditure especially on electricity in the early days was challenging. Their problems were alleviated by good price for mushroom in the market. Their mushroom was in great demand by the wholesale vegetable dealers from Bengaluru, Mangaluru, Mumbai, Pune and many other smaller towns. They had two refrigerated vans to transport the mushrooms to Pune and Mumbai. For the Southern Indian Cities like Bengaluru and Chennai, they were depending on public and private transport service. The loss of keeping quality due to this in the tropical weather was dealt effectively by treating mushrooms with chilled water before packaging and transporting in the night only.

The marketing of mushroom has been well channelized through many wholesale and retail distributors across South India, Maharashtra and Goa. Unlike other mushroom varieties, the button mushroom is in high demand in all major cities. Many traders approach the button mushroom growing entrepreneurs for marketing their mushroom. The marketing agencies deposit in advance an amount equivalent to which they place the demand regularly. With the stability in production, the mushroom project helped them to start another company named Vegi fresh Agro Exports Private Limited in 2012. With this, they concentrated on exporting part of the button mushrooms to West Asian countries.

\section{Cost of mushroom production in the unit}

Being located in tropical region, the cost incurred on the electricity and fuel was the highest (45\%) among total costs of mushroom production. The mushroom production was relying upon continuous supply of electricity to moderate the room temperature of the cropping rooms and to raise the temperature of the compost up to $66{ }^{\circ} \mathrm{C}$ during the compost pasteurization process. The total 
expenditure of the mushroom unit in one year was ₹ 40.46 million. Around 22 per cent of the expenditure was incurred on account of depreciation and interest payment of capital assets while the labour wages were to the extent of 10 per cent of this cost. Among raw materials, straw/ sugarcane bagasse accounted for highest $(7 \%)$ expenditure while the spawn, poultry manure and packaging and branding accounted for about 4 per cent each of the cost. Fertilizers/ chemicals accounted for nearly 3 per cent of the cost. The details of the share of cost of mushroom production are depicted in Figure 3. The mushroom unit produced little above $400 \mathrm{t}$ of mushroom during 2014. The price for fresh mushroom ranged from ₹ $125-140$ per $\mathrm{kg}$ at farm gate. By the weighted average price as ₹ 135 per $\mathrm{kg}$, the mushroom unit earned gross revenue of 54.05 million. Waste mushroom stipes and spent mushroom compost yielded around 1.85 million, hence the net revenue of the unit was 15.44 million during the year 2014 .

Fig.1 Map showing the location of Tigadi village in Karnataka

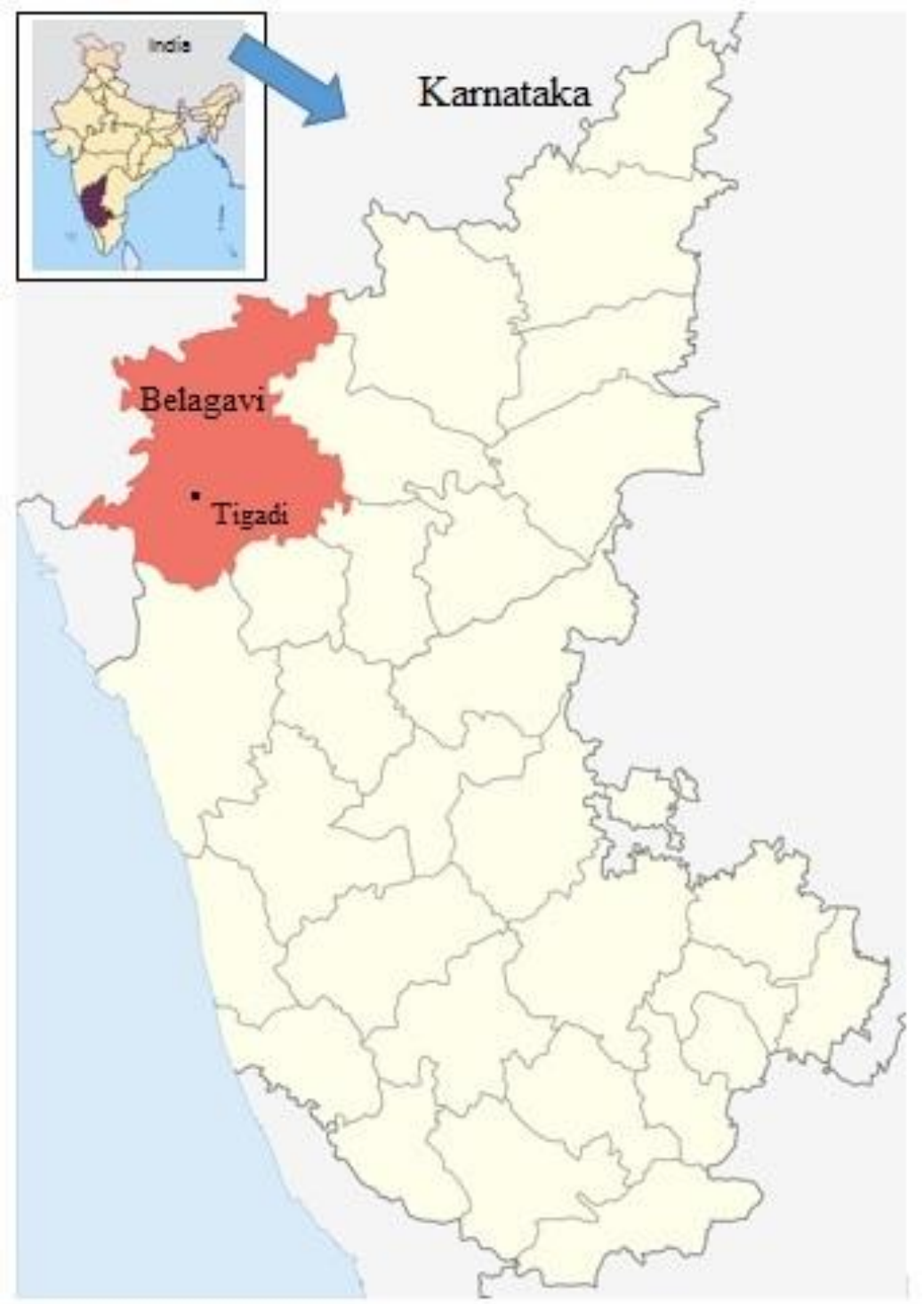


Fig.2 Capital investment for different items in the mushroom production unit

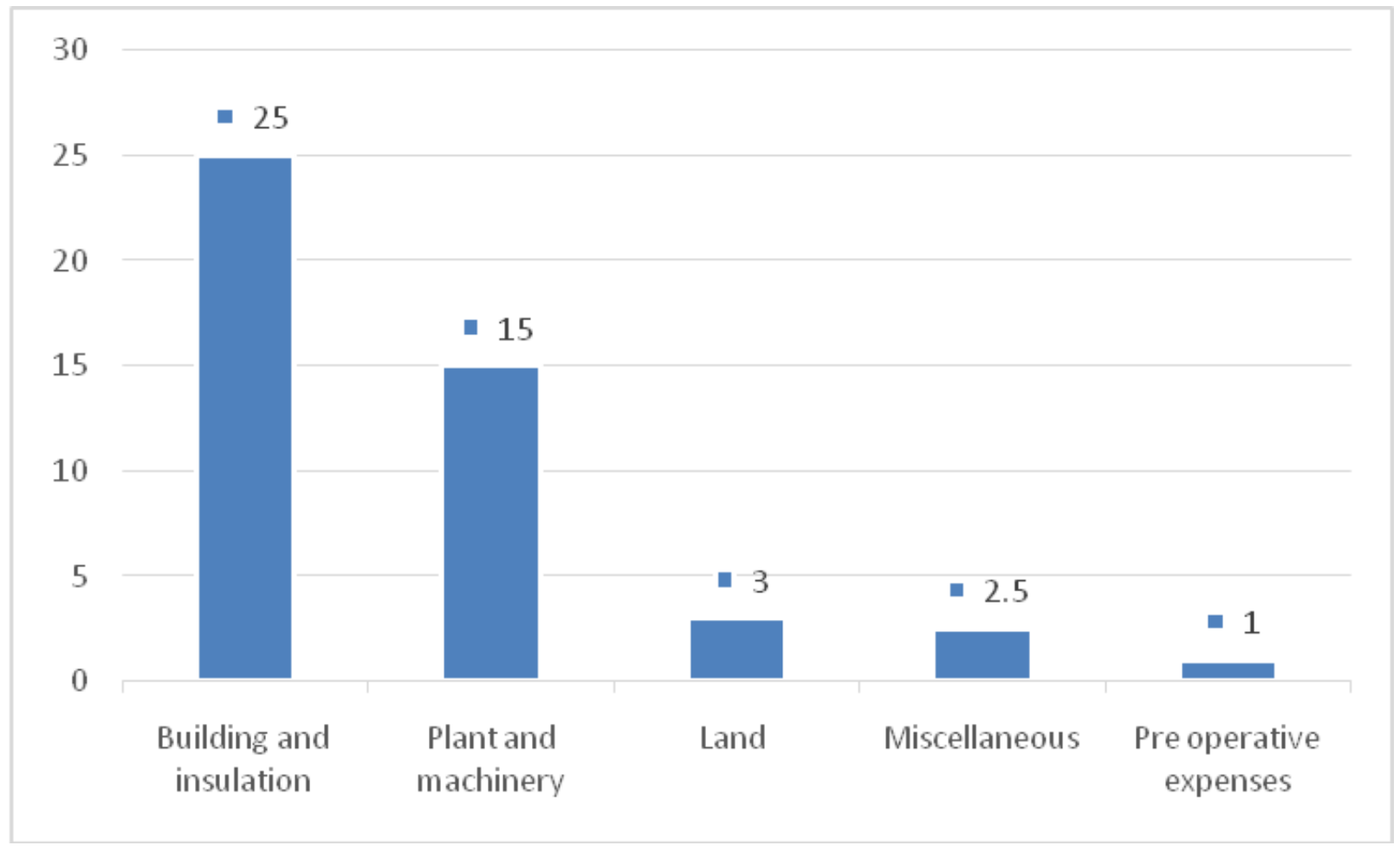

Fig.3 Proportionate cost on different components of mushroom unit

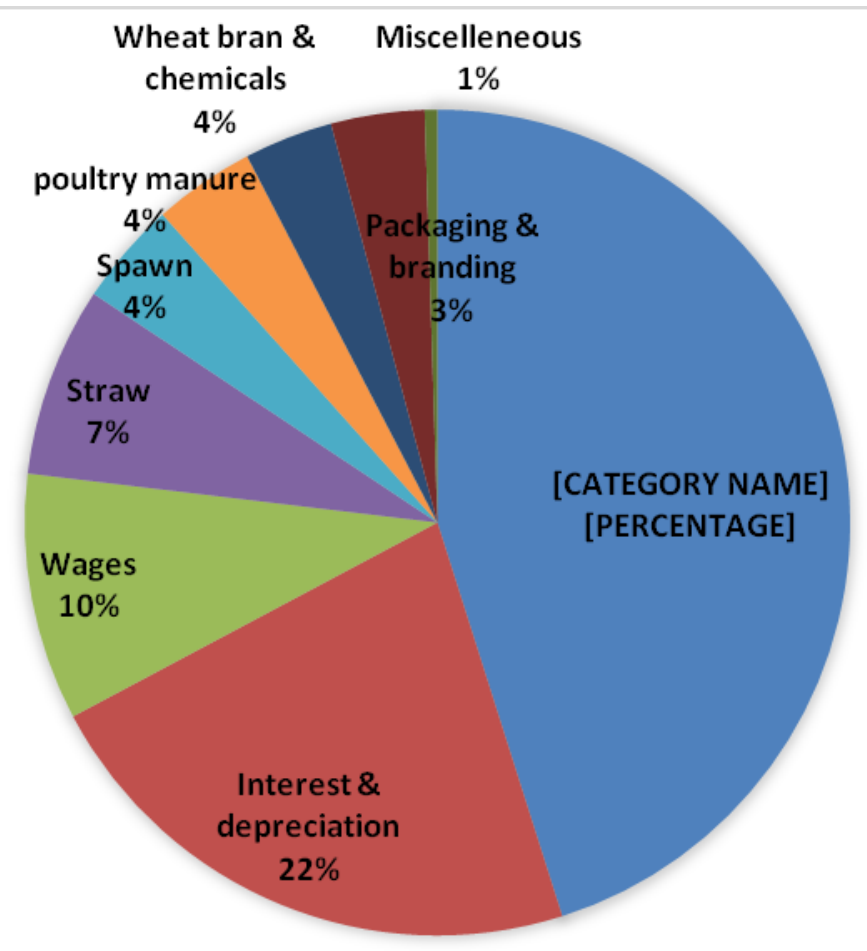


Table.1 Major Constraints reported in mushroom entrepreneurship

\begin{tabular}{|c|c|c|}
\hline S. No. & Constraints & Reference \\
\hline 1 & Farm designing & $\begin{array}{l}\text { Requires considerable capital outlay (Yehuala, 2008); } \\
\text { High cost of land acquisition (Celik and Peker, 2009); } \\
\text { Lack of technical information and exploitation by consultants } \\
\text { (Shirur, 2015). }\end{array}$ \\
\hline 2 & $\begin{array}{l}\text { Growing medium/ } \\
\text { compost preparation }\end{array}$ & $\begin{array}{l}\text { Compost preparation and casing soil preparation require elaborate } \\
\text { training (Singh } \text { et al., 2015) }\end{array}$ \\
\hline 3 & Spawn & $\begin{array}{l}\text { Lack of availability of quality spawn and high price of spawn. } \\
\text { (Singh and Suresh, 2007); } \\
\text { Non availability of quality spawn (Gautamet al., 2014) }\end{array}$ \\
\hline 4 & Crop management & $\begin{array}{l}\text { The electricity is the major constraint for white button mushroom } \\
\text { unit (Pollack, 1995andAnon., 2005); } \\
\text { "Non-availability of quality spawn" and "high electricity tariff" } \\
\text { were perceived as the main production constraints (Singh et al., } \\
2008 \text { ); } \\
\text { Time lag to obtain a return on investment, lack of funds, } \\
\text { insufficient production. (Michael et al., 2008); } \\
\text { Non availability of spawn and poor spawn quality, (Pattnaik and } \\
\text { Mishra 2008, Gateriet al., 2009) }\end{array}$ \\
\hline 5 & $\begin{array}{l}\text { Pest and disease } \\
\text { management }\end{array}$ & $\begin{array}{l}\text { Pest and disease infection are most important constraints after the } \\
\text { spawn. (Singh and Suresh, 2007) }\end{array}$ \\
\hline 6 & $\begin{array}{l}\text { Marketing and } \\
\text { economic returns }\end{array}$ & $\begin{array}{l}\text { Marketing information is the major constraint in mushroom } \\
\text { production. How to sell more mushroom than how to grow more } \\
\text { mushrooms. (Michael et al., 2008) } \\
\text { Lack of information and fluctuating price (Singh et al., 2008); } \\
\text { Lack of Marketing channels and proper markets are distantly } \\
\text { located (Gautamet al., 2014); } \\
\text { Middlemen exploit mushroom growers (Shirur and } \\
\text { Shivalingegowda, 2015; Singh and Singh, 2014) }\end{array}$ \\
\hline 7 & $\begin{array}{l}\text { Processing and value } \\
\text { addition }\end{array}$ & $\begin{array}{l}\text { Lack of cold storage and non-availability of drying equipments. } \\
\text { (Singh et al., 2008); } \\
\text { mushroom is highly perishable, lack of marketing facility } \\
\text { (Pattnaik and Mishra, 2008) }\end{array}$ \\
\hline
\end{tabular}

Analysing entrepreneurial behaviour and performance index of Mr. Shrikar

The entrepreneurial behaviour and performance index of Mr. Shrikar Kulkarni and the Kulkarni farm fresh mushroom unit were analysed. Among the button mushroom growers of Karnataka, Mr. Shrikar was having highest score on entrepreneurial behaviour among button mushroom growers and fourth highest among growers growing different varieties. Mr. Shrikar scored very high on achievement motivation, economic motivation, technical competency, decision making ability, risk bearing ability, management orientation and marketing orientation. He falls among the middle category with respect to scientific orientation, leadership ability, innovativeness and information seeking behaviour. 
On the performance index, the unit is highest with respect to scale/size of the unit (27/30) and the social capital (19/21). This is significant considering the higher weightages for scale and social capital in the performance index. Singh et al., (2010) found that, in case of mushroom cultivation the economic returns/ benefit also increased as the size of unit increased. Therefore, the economy of scale is very important for mushroom project to be viable. Moreover, the social capital for managing the inputs in time and selling the fresh mushrooms without much delay will add to the profits of the mushroom unit. Hence, the high score for Kulkarni farm fresh on both the above dimensions are the key to the success of his unit. On the machinery and infrastructure also, he is highest (12/16) but two other entrepreneurs are having matching scores. The score on machinery and infrastructure is commensurate to the large size of the unit which complements the operations of the unit. The scores of 11, 16 and 13 respectively on efficiency, good mushroom cultivation practices and incremental expansion are either second best or third best separated by two points from the highest score (Maximum possible score for these three dimensions is 15, 18 and 15 respectively). Though, the unit has not shown significant incremental growth in its size and scale, the improvement in efficiency parameters, the social capital and hygienic practices in the unit are contributing to its incremental growth dimension. While, he has scored well on good mushroom cultivation practices, there is always scope for good practices in the mushroom unit.

\section{Lessons and precautions for start-ups}

Mushroom cultivation being a complex and highly technical business needs adequate review and analysis before the potential startups venture into it. In-depth analysis of this success story must serve as a reference of lessons and precautions for such fresher in the business.

The strength of Kulkarni farm fresh is the team of young entrepreneurs led by the experienced and elderly head of the family with his timely advises. All the new generation entrepreneurs have diverse educational background with practical experience in various agri-related enterprises. $\mathrm{Mr}$ Satish has the experience of being a marketing executive and a consultant with leading multinational company- Vakrangee. He guides them about the market demands and future prospects and is updated about the recent technology in mushroom entrepreneurship. They also have the managerial support of a mechanical engineering expert Mr Sripad Jadhav for farm designing, fabrication of machinery, etc. $\mathrm{Mr}$ Shrikar looks after the linkages of input and raw materials suppliers and marketing of mushrooms. Mr Jayateerth is managing the farm operations and decisions on crop management in the mushroom production unit. Hence, the strength of Kulkarni farm fresh button mushroom unit is its coherent operations by a team of qualified young entrepreneurs. Positive effect of higher qualification on comprehension of agro advisories has also been reported by Gowda and Dixit (2015).

Being located in village in a tropical climate of South India comes with a disadvantage. The power supply is riddled with frequent load shedding and single phase electricity supply for long hours. The unit does not enjoy the policy support also for subsidized electricity. Even the fluctuating cost of diesel is adding to their cost of production. The lack of Government support to mushroom enterprises was seen as the major constraint in many other States also (Gautam et al., 2014). To reduce the cost on energy, the spent mushroom substrate (SMS) can be turned into 
briquettes for generating energy. The other option is to convert the spent substrate into biogas and make use of this energy to the mushroom unit. The records at the ICARDirectorate of Mushroom Research, Solan in India shows that no startup mushroom enterprise keeps the biogas plant as part of their project for utilising huge quantity of SMS to produce bioenergy which is also environment friendly. Hence, there is also an urgent need for technological intervention for efficient utilisation of SMS to convert it into source of bioenergy.

The unit is facing problem to get the required quantity of sugarcane bagasse from sugarcane factories for making the compost. Hence, rather than depending on single source of raw materials, the units situated in rural areas must make use of varied raw materials such as wheat straw, paddy straw, soya stalks, cotton waste, groundnut shell husks, etc, that can support the growth of mushrooms with the supplementation of starch and carbohydrates.

Plant location is just $30 \mathrm{Km}$ from Belagavi, which is ideally located at equal distance from Mumbai and Bengaluru (500 km). This helps them to transfer the finished products to the buyer within 8 to 10 hours. Goa, another major market is just $120 \mathrm{~km}$ away from the unit. Goa, Karwar and Mumbai seaports can be used for exports. Belagavi besides having good train and road connectivity also has an airport. These strategic factors are major opportunities for Kulkarni Farm Fresh. Any startup must locate the potential markets and design location specific marketing and supply chain strategies to reduce wastage.

The Kulkarni farm fresh mushroom unit being located in a village is bestowed with sufficient availability of land for expansion, clean water, and labour at nominal wages. Being in the countryside helps to get the raw materials like wheat straw, soya straw, paddy straw and sugarcane bagasse during and after cropping seasons.

With the increasing awareness among the consumers, other mushrooms are eating into the demand of the erstwhile demand for white button mushrooms. This can be considered as a major threat for this unit as it produces only white button mushrooms.

Regular supply of energy at affordable costs is one of the constraints in commercial production of mushrooms. An important good cultivation practice to cut down the energy cost is to diversify and grow different mushrooms as per the natural conditions (Singh, 2011). The advantage of vast geographical area with diverse agroecological regions in India has not yet been tapped to grow different mushrooms. The paradoxical situation of growing large quantity of temperate mushroom in the tropical country like India continues even after 50 years since the domestication of mushrooms in the country. This can be addressed by promoting easy to cultivate tropical mushrooms such as oyster mushroom, milky mushroom and paddy straw mushroom according their suitability of environment. The diversification of mushrooms, besides saving on energy cost will give additional options for both consumers and food processing sector for their consumption and business respectively.

The establishment of such a skill oriented enterprise starting in rural India opens new employment opportunities for educated folks in the villages who are otherwise turning away from traditional agriculture. Moreover, such agribusiness units demonstrate the ways to increase the labour productivity in rural areas to overcome the problem of disguised unemployment and can be an effective tool to reverse the migration. The present case study 
can be an ideal guide to other start-ups to know the profitability of mushroom entrepreneurship and also to posit their strategies to alter the cost equations to increase the profitability of the enterprise.

\section{References}

Anonymous, 2005. Proposal for establishment of mushroom spawn production laboratory under State Horticulture Mission submitted to National Horticulture Mission, GOI, New Delhi. India.

Badalyan, S.M., 2012. Edible Ectomycorrhizal Mushrooms In: Edible Ectomycorrhizal Mushrooms. Soil Biology series. Vol. 34. SpringerVerlag. A. Zambonelliand G. Bonito, Eds. Pp.317-334. ISBN: 978-3-64233822-9.

Celik, Y., and K. Peker. 2009. Benefit/ Cost Analysis of Mushroom Production for Diversification of Income in Developing Countries. Bulgarian J. Agric. Sci.15 (3), 228-237.

Gateri, M.W., A.W. Muriuki, M.W. Waiganjo, and P. Ngeli. 2009. Cultivation and commercialization of edible mushrooms in kenya: a review of prospects and challenges for smallholder production. actahortic. 806 , 473-480.

Gautam Ashok Kumar., Singh Prakash., Mishra Dheeraj, Kumar Arun and Singh Abhishek Pratap. 2014. Constraints in Adoption of Mushroom Production Enterprise. Indian Journal of Extension Education50 (1\&2): 39-41

Gils Van, J.J., 1988. Cultivation. In Cultivation of mushrooms (ed. Griensven van, L.J.L.D), Darlington mushroom laboratories. 1988, p 286.

Gowda, M. J. C., and Dixit, S. 2015. Influence of farmers educational level on comprehending, acting-upon and sharing of agro advisories. Journal of Agriculture and Rural Development in the Tropics and Subtropics. 116(2): 167-172.

Guilford, J. P., 1954. Psychometric methods. Tata McGraw-Hill Publishing Co Ltd. New Delhi.

Kumar Anjani, and Singh Rashmi. 2014. Components of successful model for economic empowerment of rural youth. Indian Journal of Extension Education50 (3 \& 4): 113-118

Marshal, E., and N.G. Nair. 2009. Make money by growing mushrooms. Rural Infrastructure and Agro-Industries Division, FAO, Rome: 53p.

Michael, A., Gold, M. Mihaela. Cernusca, and Larry. D. Godsey. 2008. A Competitive Market Analysis of the United States Shiitake Mushroom Marketplace. Hortitechnology.18 (3), 489-499.

Pattnaik, T., and S. Mishra. 2008. Constraints in adoption of mushroom cultivation technology, Asian Journal of Home Science, 3 (1), 86-89.

Satapathy, C., and Panda, S. 2014. Perception of youths towards farming as means of livelihood. Indian Journal of Extension Education50 (1\&2): 69-72.

Shirur, M., 2015. A study on mushroom entrepreneurship and consumer behaviour in Karnataka. Ph.D thesis (Unpub.) submitted to University of Agricultural Sciences, Bengaluru.

Shirur, M., and N.S. Shivalingegowda. 2015. Mushroom marketing channels and consumer behaviour: A critical analysis. Mysore J. Agric. Sci. 49(2), 390-393.

Singh Dhiraj, K., N.K. Pandey, K. Rana Rajesh, and B.P. Singh. 2015. Extent and correlates of knowledge of farmers regarding scientific potato production technologies in Himachal Pradesh. International Journal of Agriculture, Environment and Biotechnology8 (2), 381-385. 
Singh, K., R. Peshin, and S.K. Saini. 2010. Evaluation of the agricultural vocational training programmes conducted by the Krishi Vigyan Kendras (Farm Science Centres) in Indian Punjab. Journal of Agriculture and Rural Development in the Tropics and Subtropics. 111 (2), 6577.

Singh Manjit, 2011. Mushroom Production: An Agribusiness Activity. In Mushrooms cultivation, marketing and consumption (edsManjit Singh, Bhuvnesh Vijay, Shwet Kamal and Wakchaure, G.C), Directorate of Mushroom Research, Solan, 1-10.

Singh Nasib, S. Mehta, A.K. Godara, and V.P. Yadav. 2008. Constraints in mushroom production technology in Haryana, Agric. Sci. Digest, 28 (2), 118 $-120$

Singh, R., and R. Suresh. 2007. Cost-benefit analysis of mushroom cultivation. Indian J. Agric. Res. 41(4), 256-261.

Singh Surjit, and Singh, Ajay. 2014. Status and scope of mushroom cultivation in Haryana constraints and future outlook. Proceedings of the 8th International Conference on Mushroom Biology and Mushroom Products (ICMBMP8) pp.612.

Vedder, P. J. C., 1978. The position of the mushroom in the vegetable kingdom in Modern mushroom growing. Pp. 80-81.

Vijay, B., 2011. Farm design for commercial button mushroom cultivation. In Mushrooms cultivation, marketing and consumption (eds. Manjit Singh, Bhuvnesh Vijay, Shwet Kamal and Wakchaure, G.C), Directorate of Mushroom Research, Solan. 2011, 69.

Wasser, S.P., 2010. Medicinal mushroom science: history, current status, future trends and unsolved problems. Int. $J$ Med. Mushr., 12, 1-16.

Yehuala Kiflemariam, 2008. Potentials and constraints of mushroom production in Ethiopia. A Paper Presented at the National Mushroom Conference, Addis Ababa University, Ethiopia, and $16^{\text {th }}$ May, 2008

Zhang, Y., W. Geng, Y. Shen, Y. Wang, and Y.C. Dai. 2014. Edible Mushroom Cultivation for Food Security and Rural Development in China: Bio-Innovation, Technological Dissemination and Marketing. Sustainability6: 2961-2973; doi: 10.3390/su6052961.

\section{How to cite this article:}

Mahantesh Shirur, N.S. Shivalinge Gowda, M.J. Chandregowda, Sunil and Rajesh K. Rana. 2017. An Exemplary Story of Growing Temperate Mushroom in Tropical Climate of Rural India: Lessons for Other Startups. Int.J.Curr.Microbiol.App.Sci. 6(9): 2423-2433. doi: https://doi.org/10.20546/ijcmas.2017.609.298 